\title{
28. SERPENTINIZED PERIDOTITES IN THE UPPER OCEANIC CRUST AWAY FROM TRANSFORM ZONES: A COMPARISON OF THE RESULTS OF PREVIOUS DSDP AND ODP LEGS 1
}

\author{
Thierry Juteau, ${ }^{2}$ Mathilde Cannat, ${ }^{2}$ and Yves Lagabrielle ${ }^{2}$
}

\begin{abstract}
We present a synthesis of the petrology, structure, and stratigraphic position of the oceanic peridotites drilled away from transform faults, as part of the DSDP and ODP programs. This synthesis documents the fact that rocks from the deepest parts of the crust, and from the upper mantle, are rather commonly exposed on the seafloor in the immediate vicinity of the Mid-Atlantic Ridge, away from the transform fault scarps. The structural setting of the Site 670 serpentinized peridotites, cropping out just a few kilometers away from the axial volcanic ridge, helps to explain the stratigraphy of the other drilled sites in the Atlantic, where serpentinized ultramafic or ultramafic-mafic breccias either rest directly on a serpentinite basement (Sites 558 and 560), or are interbedded within the lava-flows in the uppermost levels of the crust (Sites 395 and 395A). Blocks and rubble of serpentinized peridotites, equivalent to the rocks of Site 670, may fall from submarine cliffs, and accumulate over the recent lava flows of the rift valley, to be overlain by the lava flows subsequently emitted by the axial volcanoes. The emplacement of upper mantle and lower crustal rocks on the seafloor may be a characteristic feature of slow spreading oceans: limited magma supply (i.e., limited thickness of the magmatic crust), and irregularities of the volcanotectonic cycle, with purely tectonic phases of spreading, accommodated by the stretching of the crust along normal faults.
\end{abstract}

\section{INTRODUCTION}

One of the main results of the dives of the Alvin submersible (Karson et al., 1987), and of Leg ODP 109 which took place shortly afterward (spring-summer 1986), was the discovery and sampling of serpentinized peridotites cropping out on the western flank of the Mid-Atlantic Ridge (M.A.R.) axial valley, $40 \mathrm{~km}$ south of the Kane Fracture Zone (Figs. 1 and 2). The presence of rocks from the mantle or the deep oceanic crust, in the uppermost levels of the crust away from a transform zone, cannot be explained by the classical geological interpretation of the three layers of the oceanic seismic crust. It suggests that, in some areas, magma injection and crystallization are not the only mechanism of oceanic spreading.

The area explored during Leg 109 is not the first one where serpentinized peridotites were found at very shallow levels in the crust, away from the transform fault scarps. In the Atlantic Ocean (Fig. 1), serpentinized peridotites were dredged or drilled near the M.A.R. at $6^{\circ} \mathrm{N}$ (Bonatti et al., 1975 ), at $15^{\circ} \mathrm{N}$ (Rona et al., 1987; Ridelente cruise, 1987, H. Bougault pers. comm.), between $23^{\circ} \mathrm{N}$ and $24^{\circ} \mathrm{N}$ (Leg 45, Leg 109 , and Alvin dives; Karson et al., 1987), between $35^{\circ} \mathrm{N}$ and $40^{\circ} \mathrm{N}$ (Leg 37 and Leg 82,) and between $43^{\circ} \mathrm{N}$ and $46^{\circ} \mathrm{N}$ (dredging results reported by Phillips et al., 1968, and Aumento and Loubat, 1971). These areas may not be unique: drilling in other nontransform localities most often stopped at, or just below the sediment/basement (basalt) contact, and large segments of the M.A.R. rift valley walls have not yet been sampled.

Away from the M.A.R., serpentinized peridotites from nontransform environments have been recovered at two drilled sites: Site 637, at the foot of the Galicia continental

\footnotetext{
${ }^{1}$ Detrick, R., Honnorez, J., Bryan, W. B., Juteau, T., et al., 1990. Proc. ODP, Sci. Results, 106/109: College Station, TX (Ocean Drilling Program).

2 'GIS "Océanologie et Géodynamique," Université de Bretagne Occidentale, 6 Avenue Le Gorgeu, 29293 Brest Cedex, France.
}

margin (Leg ODP 103), and Site 651 in the Tyrrhenian Sea (Leg ODP 107). Site 637 (Fig. 1) was located on the top of a ridge, parallel to the Galicia Margin, and close to the very first tilted blocks belonging to the continental margin (Shipboard Scientific Party, 1987b). In the Tyrrhenian Sea, Site 651 (Fig. 1) was located in the small Vavilov Oceanic Basin on a ridge interpreted as a fossil embryonic spreading axis (Kastens et al., 1986). Blocks of serpentinized peridotite have also been dredged on a ridge, parallel to the southwest Australian margin (Nicholls et al., 1981). It is significant that all these sites lie very close to a passive continental margin. The crust at these sites is therefore probably contemporaneous with the very first stages of seafloor spreading at a rifted continental margin.

In this paper, we present a synthesis of the petrology, structure, and stratigraphic position of the oceanic peridotites drilled away from transform zones as part of the DSDP and ODP programs. We choose not to discuss the dredged samples, as our focus is primarily on the stratigraphic relationships between the serpentinized peridotites and the other crustal units. We outline similarities, such as the stratigraphic evidence found in all the M.A.R. sites for an emplacement of the peridotites on the seafloor of the median valley. We also briefly discuss the possible mechanisms of emplacement.

\section{MAIN PETROLOGICAL AND STRUCTURAL FEATURES OF THE SERPENTINIZED PERIDOTITES}

The protoliths of the serpentinized peridotites drilled at Site 334 (Leg 37), west of the FAMOUS Area (Figs. 1 and 3), are troctolites and lherzolites, interlayered with gabbros (Fig. 4). They are most probably of cumulate origin (Shipboard Scientific Party, 1977). The other serpentinized peridotites, drilled during Leg 45, 82, 103, 107, and 109, are harzburgites, with occasional lherzolitic intervals in the case of Legs 45 and 109. The petrology of the Leg 107 serpentinized peridotites has not yet been published. The Leg 45, 82, 103, and 109 peridotites have chemical and textural features thought to be typical of mantle peridotites (Arai and Fujii, 1979; Sinton, 


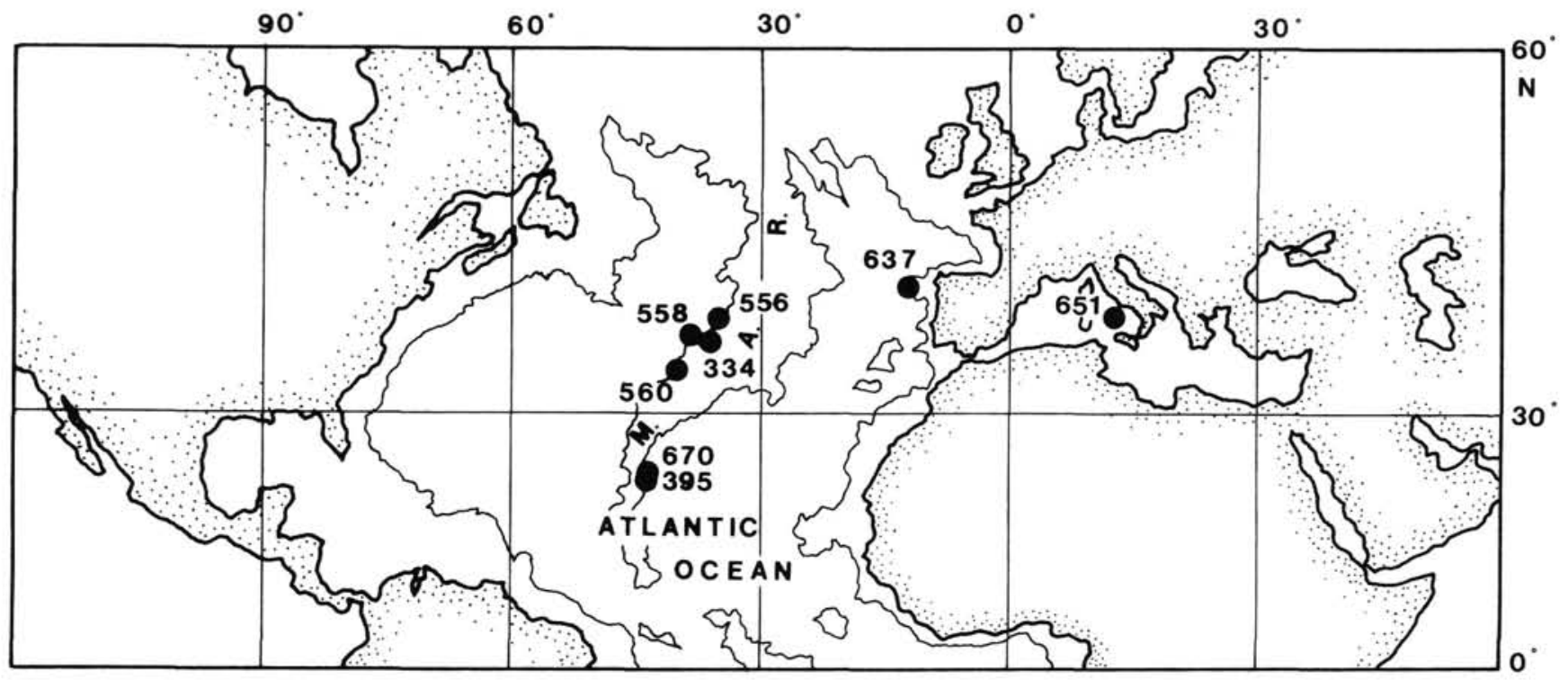

Figure 1. Location of the sites where peridotites have been drilled in the uppermost crust as part of the DSDP and ODP programs.

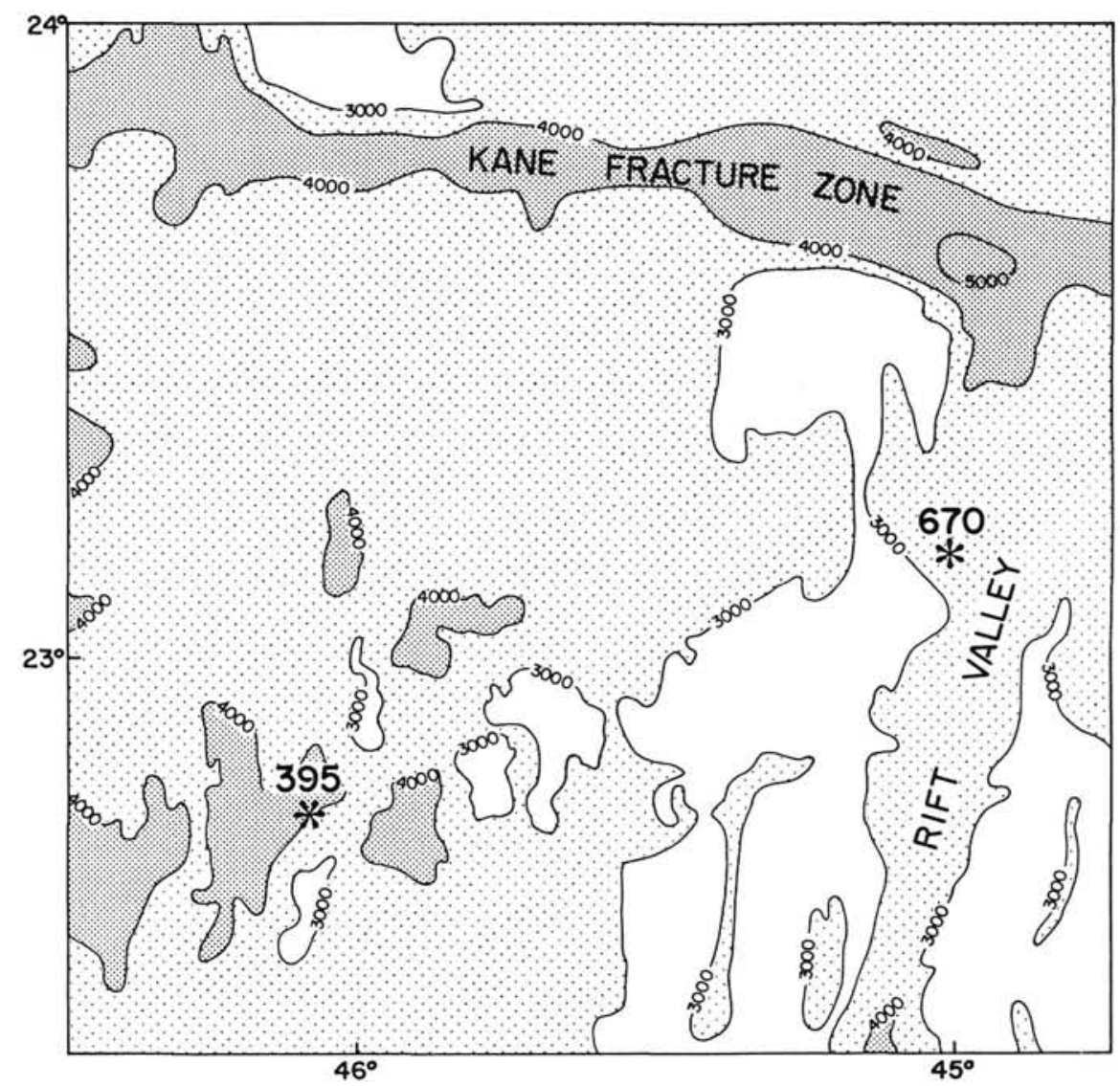

Figure 2. Location of Sites 395 and 670 in the area south of the Kane Fracture Zone.

1979; Boudier, 1979; Michael and Bonatti, 1985a; Shipboard Scientific Party, 1987a; Evans and Girardeau, 1988; Kornprobst and Tabit, 1988; Shipboard Scientific Party, 1987b).

The Leg 103 serpentinized peridotites, drilled at Site 637 close to the Galicia Margin (Fig. 1), are derived from feldsparbearing harzburgites. They are strongly deformed under the stress and temperature conditions expected within the deep lithosphere (high deviatoric stresses and temperatures probably below $1000^{\circ} \mathrm{C}$; Girardeau et al., 1988). Their mineral chemistry (Evans and Girardeau, 1988; Kornprobst and Tabit, 1988) as well as their structural position (Shipboard Scientific Party, 1987b) suggest that they represent subcontinental mantle uplifted along a major extensional ductile shear zone (Boillot et al., 1987). In contrast, the Leg 107 harzburgites, 


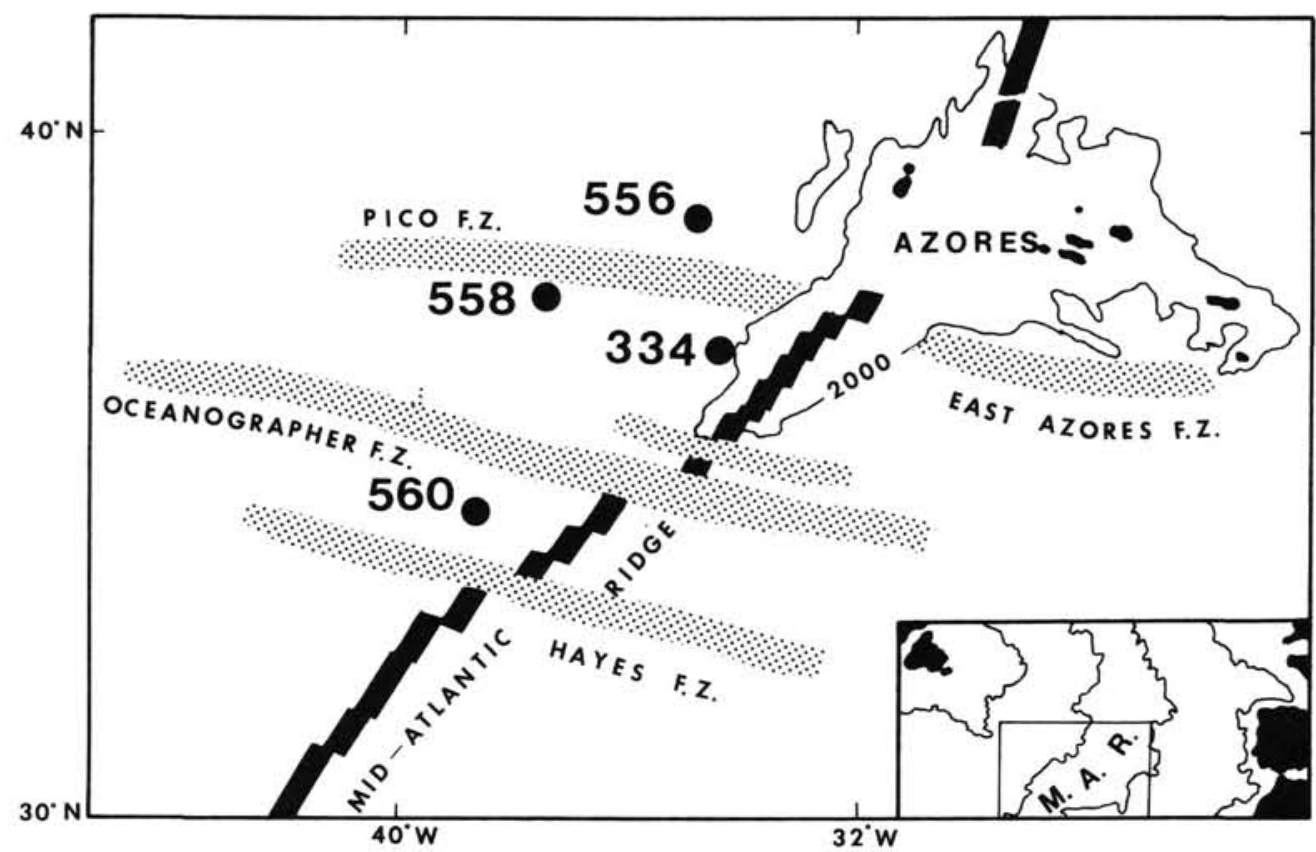

Figure 3. Location of Sites 334, 556, 558, and 560 in the area west of the FAMOUS region.

drilled at Site 651 in the Tyrrhenian Sea (Fig. 1), are only moderately deformed and do not contain feldspar (Girardeau, pers. comm.).

In the Atlantic, the Leg 45, 82, and 109 serpentinized peridotites also do not contain feldspar. The serpentinized harzburgites drilled west of the FAMOUS Area (Sites 556, 558 , and 560 of Leg 82; Fig. 3) have undergone high degrees of partial melting (Michael and Bonatti, 1985a). The serpentinized peridotites drilled south of the Kane Fracture Zone (Sites 395, 395A of Leg 45, and Site 670 of Leg 109; Fig. 2) are comparatively less depleted (Arai and Fujii, 1979; Sinton, 1979; Juteau et al., this volume). This difference in the estimated amount of extracted melt may be related to a regional variability, as the serpentinized peridotites dredged on seamounts and in transform zones in the vicinity of the FAMOUS Area are also more depleted (Michael and Bonatti, 1985b). The serpentinized mantle peridotites drilled in the Atlantic (Legs 45, 82, and 109) are deformed in inferred asthenospheric conditions (temperatures above $1000^{\circ} \mathrm{C}$ and low to moderate deviatoric stresses), but a few samples also show evidence for a very restricted deformation occurring under high deviatoric stresses, probably in the lithosphere (Boudier, 1979; Cannat et al., this volume; Cannat, unpubl. data).

Lastly, an important similarity between the peridotites from all the sites mentioned in this paper is that their serpentinization, often very extensive, is always static. It was not accompanied, nor followed, by significant deformations (Helmstaedt and Allen, 1977; Boudier, 1979; Girardeau et al., 1988; Girardeau, comm. pers.; Cannat et al., this volume and unpubl. data). However, material from discrete serpentinite shear zones may have been preferentially washed away during the coring operations, as suggest for example in the case of Site 670 (Cannat et al., this volume).

\section{STRATIGRAPHIC POSITION OF THE SERPENTINIZED PERIDOTITES}

The serpentinized peridotites of Sites 395 and 395A, south of the Kane Fracture Zone (Leg 45; Fig. 2), occur as two 1-m-thick intervals, associated with a carbonate cemented mafic-ultramafic breccia which is interlayered in the basalt sequence (Fig. 4). Their stratigraphic position indicates that they are reworked blocks, fallen from a nearby cliff before the end of the volcanic activity in the area (Shipboard Scientific Party, 1979).

Isolated serpentinized peridotite fragments also occur in the upper sedimentary unit of Site 395 (Fig. 4). This indicates that peridotites repeatedly (and perhaps continuously) cropped out in the area during a long period of time (the sedimentary sequence ranges from the upper Miocene to the upper Pliocene; Shipboard Scientific Party, 1979).

Intervals of carbonate-cemented breccias with nannofossils occur within the interlayered serpentinized peridotitegabbro sequence of Site 334 (Shipboard Scientific Party, 1977; Fig. 4). These breccias may underline cataclastic faults in an otherwise coherent cumulate sequence (Helmstaedt and Allen, 1977). Alternatively, the breccia may be a sedimentary formation, including the intervals of serpentinized peridotite and gabbro cumulates as large blocks. In any case, the presence of nannofossils in the carbonate matrix of the breccia indicates that the serpentinized peridotitegabbro sequence was cropping out before the emplacement of the overlying basalts (Shipboard Scientific Party, 1977).

There is no indication that the serpentinized peridotites drilled during Legs 82 and 107 are themselves part of a sedimentary breccia (there is no definite proof to the contrary, either), but they are separated from the overlying basalt flows by brecciated intervals (Fig. 4), interpreted as talus deposits (Shipboard Scientific Party, 1985; Kastens et al., 1986).

Thus, the stratigraphic position of the Leg $37,45,82$, and 107 serpentinized peridotites indicates that they once cropped out in, or adjacent to, a volcanically active zone. This volcanically active zone was presumably the axial valley itself, at least in the case of the M.A.R. sites. This interpretation is supported by the stratigraphy and setting at Site 670 (Leg 109; Fig. 1), drilled in the lower west wall of the M.A.R. axial valley, where the peridotites are capped by only a few meters of sediments (Fig. 4). 

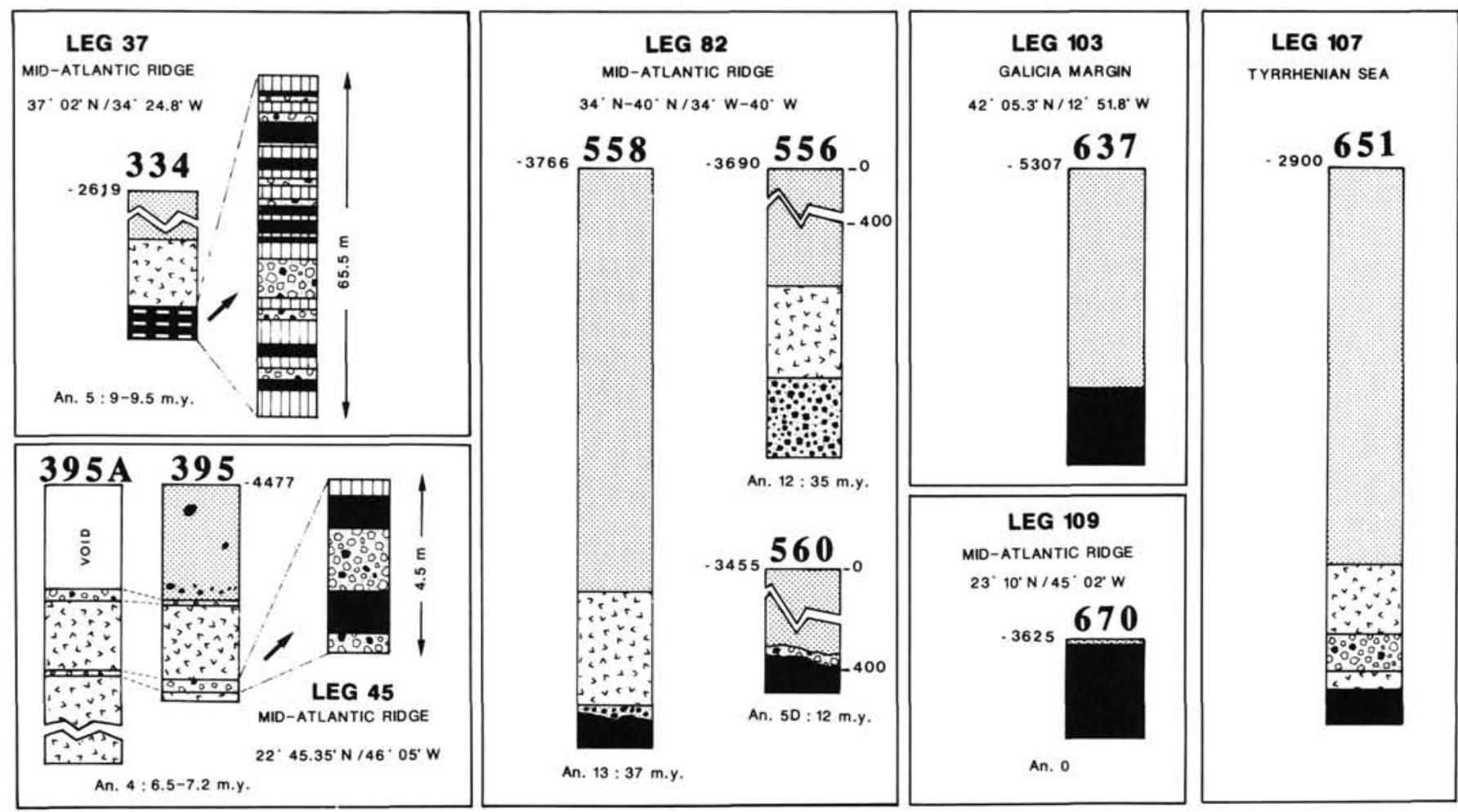

Depths in meters
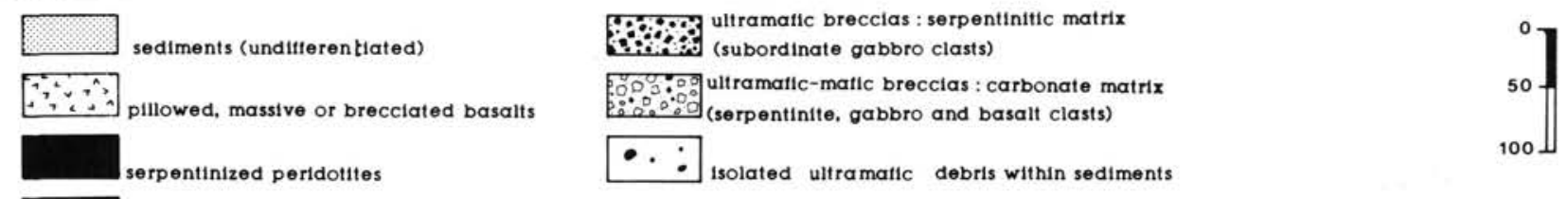

Figure 4. Stratigraphic columns for Sites 334, 395, 556, 558, 560, 637, 651, and 670. Compiled and modified from Shipboard Scientific Party (1977; 1979; 1985; 1987b) and Kastens et al. (1986).

The possibility that the serpentinized peridotites may be fallen blocks can be ruled out at Site 637 (Galicia Margin, Leg 103; Fig. 1). The site is located on the top of a ridge (Shipboard Scientific Party, 1987a), and the textures and structures of the peridotites are coherent over more than $70 \mathrm{~m}$ in depth (Girardeau et al., 1988). Lastly, in the M.A.R. region, the age of the crust (based on the magnetic anomalies) varies significantly from one site to another (Shipboard Scientific Party, 1977; 1979; 1985; 1987b), and some sites are located almost along the same flow line (Figs. 2 and 3). To the south of the Kane Fracture Zone (Fig. 1), Site 670 (Leg 109) lies in the median valley and Sites 395 and 395A (Leg 45) lie on anomaly 5 (6.5 m.y. to 7.2 m.y.). To the west of the FAMOUS Area (Fig. 3), Site 334 (Leg 37$)$ is on anomaly 5 ( 9 m.y.), Site 560 (Leg 82) is on anomaly $5 \mathrm{D}(12 \mathrm{~m} . \mathrm{y}$.$) , Site 556(\operatorname{Leg} 82)$ is on anomaly 12 (35 m.y.) and Site $558(\operatorname{Leg} 82)$ is on anomaly $13(37$ m.y.). The presence of peridotites at shallow levels at all these sites attests to the long lasting, or to the frequent activation over long periods of time, of the processes responsible for the emplacement of mantle or lower crustal rocks on the seafloor of the median valley.

\section{SUMMARY AND CONCLUSION}

Seismic reflection and refraction studies in the oceans and correlations with the ophiolitic stratigraphy have favored the pop- ular model of a "three-layers" standard section for the oceanic crust (sediment, basalt, and gabbro layers, respectively, overlying the upper mantle peridotites). Historically, large submarine escarpments have been used as windows into the deepest levels of the oceanic crust and the upper mantle. Dredging programs on both ridge-parallel and ridge-perpendicular submarine scarps, mainly along fracture-zones, have yielded a wide range of rock-types obviously coming from below the yolcanic carapace of the oceanic crust, including gabbros, metagabbros, diabases, greenstones, and serpentinized peridotites (Melson et al., 1968; Miyashiro et al., 1969; Melson and Thompson, 1971; Aumento and Loubat, 1971; Bonatti et al., 1975; Engel and Fisher, 1975; Bonatti and Honnorez, 1976; Prinz et al., 1976; Hamlyn and Bonatti, 1980; Hébert et al., 1983). More recently, upper crustal seismic layers in the vicinity of major offset transform faults were found to be thinner than predicted by the "three layers" models (Purdy and Detrick, 1986; Fox and Gallo, 1984). Listric normal faulting processes were invoked by Dick et al. (1981), and by Karson and Dick (1984) to explain the wide range of deep crustal rocks exposed at the active corners of the Kane Fracture Zone. The alternative hypothesis (Bonatti and Honnorez, 1976; Francis, 1981) involves serpentinite diapirism.

The results compiled in this paper constitute a growing body of evidence suggesting that rocks from the deepest parts 
of the crust and from the upper mantle are commonly exposed on the seafloor in the immediate vicinity of the slow spreading Mid-Atlantic Ridge and away from the transform fault scarps. The stratigraphic position of these lower crustal and mantle rocks further suggests that these deep rocks were exposed either continuously or repeatedly on the median valley seafloor during rather long periods of time: at least from $37 \mathrm{~m} . \mathrm{y}$. (Hole 558) to 0.5 m.y. (Hole 670).

The structural setting of the Site 670 serpentinized mantle peridotites, cropping out just a few kilometers away from the axial volcanic ridge, helps to explain the stratigraphy of the other drilled sites of the Atlantic, where serpentinized ultramafic or ultramafic-mafic breccias either rest directly on a serpentinite basement (Holes 558, 560), or are interbedded within the lava-flows in the uppermost levels of the crust (Holes 395, 395A). Blocks and rubble of serpentinized peridotites, equivalent to the rocks of Site 670 , may become detached from submarine cliffs, roll and accumulate over the recent lava flows of the rift valley, and be overlain by the lava flows subsequently emitted by the axial volcanoes.

Karson et al. (1987) suggested that the mantle rocks were exposed in the median valley south of the Kane Fracture Zone during purely tectonic phases of spreading, characterized by the total absence of magmatic construction: the thinning and stretching of the crust, helped by low angle normal and listric normal faulting and by block rotations, would result in the exposure on the seafloor of deep crustal rocks and upper mantle peridotites. As far as we know, exposures of mantle rocks away from transform zones are not observed along the East Pacific Rise and other fast spreading centers, where higher rates of magma production and more continuous magmatic activity have apparently produced an oceanic crust of more uniform and substantial thickness (e.g., Hole 504B). This suggests that a highly heterogeneous crustal structure, significantly different from the "three-layers" standard model, is likely to be characteristic of slow spreading oceans such as the Atlantic. Large variations in magma supply and frequent irregularities of the volcanotectonic cycle along the axis of the M.A.R. can explain this heterogeneity.

Outside the M.A.R. region, the two sites in which serpentinized peridotites have been drilled in the uppermost crust away from transform faults lie very close to a recent or ancient passive continental margin (Galicia Margin for Site 637, Calabria and Sardinia Margins for Site 651). The structural setting of both sites suggests that the emplacement of the peridotites was contemporaneous with the very early stages of seafloor spreading of a rifted margin. The analysis of the Red Sea case suggests that, during these early stages, the plate velocities were low (Le Pichon and Francheteau, 1978) and the magma supply limited and discontinuous (Bonatti, 1985). A parallel with the situation in the slow spreading Atlantic can therefore be tentatively drawn: low plate velocities and limited magma supply resulting in the production of a thin magmatic crust, and in the further thinning of this crust, or of the whole lithosphere, along normal faults. In this model, serpentinite diapirism may occur during the last stages of the process, as faults and fractures allow seawater to circulate through the thinned crust, into the mantle peridotites. In contrast, serpentinites at Site 637 (Galicia Margin) represent upper mantle material probably of subcontinental, rather than suboceanic, origin, that was emplaced during the stretching and rifting of the Galician continental lithosphere about 110 m.y. ago (Boillot et al., 1987). The intense deformation of the Site 637 peridotites in the lithosphere, when compared with the limited lithospheric deformation undergone by the serpentinized peridotites from the Atlantic sites, may reflect the fact that the rifting of a thick continental lithosphere involved a considerably larger strain than the stretching of the thin oceanic crust, or lithosphere, of the M.A.R. median valley.

\section{REFERENCES}

Arai, S., and Fujii, T., 1979. Petrology of ultramafic rocks from site 395. In Melson, W. G., Rabinowitz, P.D., et al., Init. Repts, DSDP, 145, Washington (U.S. Govt. Printing Office), 587-594.

Aumento, F., and Loubat, H., 1971. The Mid-Atlantic ridge near $45^{\circ} \mathrm{N}$. Serpentinized ultramafic intrusions. Can.J. Earth Sci., 8:631-663.

Boillot, G., Recq, M., Winterer, E. L., et al., 1987. Tectonic denudation of the upper mantle along passive continental margin: a model based on drilling results (ODP Leg 103, western Galicia margin, Spain). Tectonophysics, 132:335-342.

Bonatti, E., 1985. Punctiform initiation of seafloor spreading in the Red Sea during transition from a continental to an oceanic rift. Nature, 316:33-37.

Bonatti, E., Honnorez, J., Kirst, P., and Radicati, F., 1975. Metagabbros from the Mid Atlantic Ridge at $6^{\circ} \mathrm{N}$ : contact-hydrothermaldynamic metamorphism beneath the axial valley. J. Geol., 83:61-78.

Bonatti, E., and Honnorez, J., 1976. Sections of the earth's crust in the equatorial Atlantic. J. Geophys. Res., 81:4104-4116.

Boudier, F., 1979. Microstructural study of three peridotite samples drilled at the western margin of the Mid-Atlantic ridge. In Melson, W. G., Rabinowitz, P. D., et al., Init. Repts., DSDP, 45, Washington (U.S. Govt. Printing Office), 603-608.

Dick, H.J.B., Thompson, G., and Bryan, W. B., 1981. Low angle faulting and steady-state emplacement of plutonic rocks at ridgetransform intersections. EOS, 62:406.

Engel, C. G., and Fisher, R. L., 1975. Granitic to ultramafic rock complexes of the Indian Ocean Ridge system, western Indian Ocean. Geol. Soc. Am. Bull., 86:1553-1578.

Evans, C. A., and Girardeau, J., 1988. Galicia Margin peridotites; undepleted abyssal peridotites from the North Atlantic. In Boillot, G., Winterer, E. L., et al., Proc. ODP, Sci. Results, 103: College Station, TX (Ocean Drilling Program), 195-207.

Fox, P. J., and Gallo, D. G., 1984. A tectonic model for ridgetransform-ridge plate boundaries: implications for the structure of oceanic lithosphere. Tectonophysics, 104:205-242.

Francis, T. G., 1981. Serpentinization faults and their role in the tectonics of slow spreading ridges. J. Geophys. Res., 86:1161611622.

Girardeau, J., Evans, C. A., and Beslier, M. O., 1988. Structural analysis of plagioclase-bearing peridotites emplaced at the end of continental rifting: Hole 637A, ODP Leg 103 on the Galicia Margin. In Boillot, G., Winterer, E. L., et al., Proc. ODP, Sci. Results, 103: College Station, TX (Ocean Drilling Program), 209-223.

Hamlyn, P. R., and Bonatti, E., 1980. Petrology of mantle-derived ultramafics from the Owen Fracture Zone, northwest Indian Ocean: implications for the nature of the oceanic upper mantle. Earth Planet. Sci. Lett., 48:65-79.

Hébert, R., Bideau, D., and Hekinian, R., 1983. Ultramafic and mafic rocks from the Garret Transform Fault near $13^{\circ} 30^{\prime} \mathrm{S}$ on the East Pacific Rise: igneous petrology. Earth Planet. Sci. Lett., 65: $107-125$.

Helmstaedt, H., and Allen, J. M., 1977. Metagabbronorite from DSDP hole 334: an example of high-temperature deformation and recrystallization near the Mid- Atlantic Ridge. Can. J. Earth Sci., 14:886-898.

Karson, J. A., and Dick, H.J.B., 1984. Deformed and metamorphosed oceanic crust on the Mid-Atlantic Ridge. Ofioliti, 9:279-302.

Karson, J. A., Thompson, G., Humphris, S. E., et al. 1987. Along axis variations in seafloor spreading in the MARK area. Nature, 328:681-685.

Kastens, K., Mascle, J., Auroux, C., et al., 1986. La campagne 107 du Joides Resolution (Ocean Drilling Program) en Mer Tyrrhénienne: premiers résultats. C.R. Acad. Sci. Paris, 303:391-396.

Kornprobst, J., and Tabit, A., 1988. Plagioclase-bearing ultramafic tectonites from the Galicia margin (Leg 103, Site 637). Comparison of their origin and evolution with low-pressure ultramafic bodies in 
western Europe. In Boillot, G., Winterer, E. L., et al., Proc. ODP, Sci. Results, 103: College Station, TX (Ocean Drilling Program), 253-268.

Le Pichon, X., and Francheteau, J., 1978. A plate-tectonic analysis of the Red Sea-Gulf of Aden area. Tectonophysics, 46:369-406.

Melson, W. G., Thompson, G., and Van Andel, T. H., 1968. Volcanism and metamorphism in the Mid-Atlantic Ridge, $22^{\circ} \mathrm{N}$ latitude. J. Geophys. Res., 73:5925-5941.

Melson, W. G., and Thompson, G., 1971. Petrology of a transform zone and adjacent ridge segments. Phil. Trans. Geol. Soc. London, 268:423-441.

Michael, P. J., and Bonatti, E., 1985a. Petrology of ultramafic rocks from sites 556, 558 and 560 in the North Atlantic. In Bougault, H., Cande, S. C., et al., Init. Repts. DSDP, 182: Washington (U.S. Govt. Printing Office), 523-530.

1985b. Peridotite composition from the North Atlantic: regional and tectonic variations and implications for partial melting. Earth Planet. Sci. Lett., 173:91-104.

Miyashiro, A., Shido, F., and Ewing, M., 1969. Composition and origin of serpentinites from the Mid-Atlantic Ridge near $24^{\circ}-30^{\circ} \mathrm{N}$ latitude. Contrib. Mineral. Petrol., 23:117-127.

Nicholls, I. A., Ferguson, J., Jones, H., Marks, G. P., and Mutter, J. C., 1981. Ultramafic blocks from the ocean floor southwest of Australia. Earth Planet. Sci. Lett., 56:362-374.

Phillips, J. D., Thompson, G., Bowen, V. T., and Von Herzen, R. P., 1968. Geophysical and geological study of the Mid-Atlantic Ridge. Trans. Am. Geophys. Union, 49:327-328.

Prinz, M., Keil, K., Green, J. A., Reid, A. M., Bonatti, E., and Honnorez, E., 1976. Ultramafic and mafic dredge samples from the equatorial Mid-Atlantic Ridge and Fracture Zones. J. Geophys. Res., 23:4087-4103.
Purdy, G. M., and Detrick, R. S., 1986. Crustal structure of the Mid-Atlantic Ridge at $23^{\circ} \mathrm{N}$ from seismic refraction studies. $J$. Geophys. Res., 91:3739-3762.

Rona, P. A., Widenfalk, L. and Boström, K., 1987. Serpentinized ultramafics and hydrothermal activity at the Mid-Atlantic Ridge crest near $15^{\circ}$ N. J. Geophys. Res., 92:1417-1427.

Shipboard Scientific Party, 1977. Site 334. In Aumento, F., Melson, W. G., et al.. Init. Repts. DSDP, 37, Washington (U.S. Govt. Printing Office), 201-238. 1979. Site 395: $23^{\circ} \mathrm{N}$, Mid-Atlantic Ridge. In Melson, W. G., Rabinowitz, P. D., et al., Init. Repts, DSDP, 45, Washington (U.S. Govt. Printing Office), 131-264.

, 1985. Site Reports. In Bougault, H., Cande, S. C., et al., Init. Repts. DSDP, 82, Washington (U.S. Govt. Printing Office), 61-244.

1987a. Introduction, objectives, and principal results: Ocean Drilling Program Leg 103, West Galicia Margin. In Boillot, G., Winterer, E. L., et al. Proc.ODP, Init. Repts., 103: College Station, TX (Ocean Drilling Program), 3-18.

1987b. Site 637. In Boillot, G., Winterer, E. L., et al. Proc.ODP, Init. Repts., 103: College Station, TX (Ocean Drilling Program), 123-220.

Sinton, J. M., 1979. Petrology of alpine-type peridotites from site 395, DSDP Leg 45. In Melson, W. G., Rabinowitz, P. D., et al., Init. Repts, DSDP, 45, Washington (U.S. Govt, Printing Office), 595-602.

Date of initial receipt: 21 March 1988

Date of acceptance: 28 April 1989

Ms 106/109B-162 